\title{
ТЕРМІНИ ГАЛУЗІ ДОРОГОБУДІВНИЦТВА, СТВОРЕНІ ШЛЯХОМ СКЛАДАННЯ ОСНОВ І ЦЛИХ СЛІВ
}

У статті репрезентовано специфіку творення термінів-композитів та юкстапозитів у терміносистемі дорожнього будівництва. Доведено, що словоскладання та основоскладання в УДБТс найбільшого поширення набуло в трьох виділених тематичних груnax, у які об'єднані назви конкретних предметів і їх ознак. Зазначено, що на сучасному етапі розвитку української дорожньо-будівельної терміносистеми актуальною є тенденція активізації юкстапозиції й композиції як семантично ємних способів словотвору.

Ключові слова: складання основ і цілих слів (композиція та юкстапозиція); УДБТс українська дорожньо-будівельна термінологія; ТГ- термінологічна група; ДБ - дорожне будівництво.

Knyshenko N. P. Road-Building Terms Created by Compounding Stems and Whole Words. The relevance of the article is due to the consideration of current trends in the development of Ukrainian road-building terminology (URBT), in particular in the context of structural organization.

The purpose of the investigation is analyzing road-building terms formed by compounding words or stems.

Since URBT is part of the lexical composition of the Ukrainian language, it is quite reasonable to analyze the formation of terms as lexical units. We have classified single-word terms into simple and complex ones by identifying the word-forming stems. The concept "simple" denotes terms with a single stem. The notion "complex" concerns composite terms, which are formed by combining stems using interfixes and in some cases suffixes, and juxtaposite terms, which express one concept but are formed by combining several words into a complex one. According to the lexical and grammatical characteristics of word-forming stems and word-forming means, the methods of word-formation are divided into several types, among which we have chosen one of the most common - the morphological one.

At the present stage of the development of RBT, the methods of juxtaposition and composition play an extremely important role, providing the formation of terms satisfactory in their parameters. The actualization of these methods is conditioned by the fact that striving for completeness of a certain scientific concept can be sufficiently supported by multi-stem or multi-word nominates represented as one word. The carried out analysis of composite terms of the RB industry has shown that two-stem complex formations predominate among them, but terms with several stems are also present.

Key words: composition; juxtaposition; URBT-Ukrainian road-building terminology, $R B-$ road-building.

\section{Вступ}

Загальновідомим фактом є те, що переважна більшість українських слів утворюється за допомогою морфологічного способу, одним із різновидів якого є складання основ і цілих слів (композиція та юкстапозиція). Створення термінів шляхом складання основ і цілих слів, зауважують науковці, стало досить продуктивним завдяки тому, що часто дійсно виникає необхідність виразити дві ідеї в одному слові (Марченко, 1980: 38). В. Лопатін спосіб утворення складних слів уважає найбільш очевидним, унаочнюваним і найекономнішим способом заміни словосполучення словом, адже одне таке слово в змозі передати те ж саме поняття, що й ціле словосполучення (Лопатін, 1973: 41). 


\section{Методи та методики дослідження}

У дослідженні засадничим для роботи став прийом структурного аналізу - для виявлення словотворення термінів. Оскільки УДБТс є частиною лексичного складу української мови, то цілком закономірно аналізувати словотвірні процеси термінів як лексичних одиниць. Однослівні терміни ми диференціювали на прості та складні шляхом виділення твірних основ слів. Під поняттям прості розуміються терміни з однією основою: асфальтени, розміт$\kappa a$. Поняттям складні, а саме, досліджувані нами, охоплені терміни-композити, що утворені завдяки поєднанню основ із допомогою інтерфіксів, а в ряді випадків і суфіксів: бетонотранспортер, бітумогравійний, великопрольотний, газогенератор, геологорозвідка, каменедробарка, терміни-юкстапозити, що виражають одне поняття, але утворені поєднанням кількох слів в одному складному: вулкан-азбест, глиніт-цемент, крекінг-установка, скрепер-волокуша. За лексико-граматичним характером словотвірної бази та словотвірних засобів способи словотворення розподіляють на декілька типів, серед яких ми обрали один із найпоширеніших - морфологічний.

\section{Результати та дискусії}

Основоскладання передбачає поєднання основ слів за допомогою інтерфіксів або без них. Часто основоскладання супроводжується суфіксацією, суфікс увіходить до складу форманта. Такі слова ще називають композитами (лат. compositus - складний, складений із частин). Аналіз термінів-композитів галузі ДБ засвідчив, що серед них переважають двоосновні складні утворення. За структурно-морфологічними ознаками бінарні термінолексемикомпозити УДБТ поділяються на такі типи:

- субстантивно-субстантивні (іменник + іменник) $(\mathrm{N}+\mathrm{N})$ : асфальтозавод, бетонолом, водомагістраль, грязевідстійник, залізоцегла, цементобетон;

- нумеративно-субстантивні (иислівник + іменник + суфікс) $(\mathrm{Num}+\mathrm{N})$ : двоконсольний, трьохарковий, чотирипрольотний, n'ятишаровий;

- прономінативно-вербальні (займенник + дісслово + суфікс) $(\operatorname{ProN}+$ V): самовисихання, самогальмування, самонавантажувач, самонапруженість, самоперекидач, самоущільнення.

Іноді трапляються терміни з декількома основами, наприклад: автобетономішалка, армопінобетон, армопіносилікат, високотермостійкий, дьогтебітумнополімерний, дегідрополіконденсація, сталезалізобетонний та ін., однак частина з них утворена поєднанням двох основ, одна з яких уже композитна (армо- + пінобетон, високо- + термостійкий).

За походженням словотворчих компонентів можна виділити такі моделі складних слів УДБТ:

- національний компонент + іншомовний компонент чи навпаки: $a c-$ фальторозігрівач, глинобетон, корозієстійкий, карболанцюговий;

- національний компонент + національний компонент: водовбирний, землекоп, канавокопач, каменедробильник, поштовхомір, повітроочисник;

- іншомовний компонент + іншомовний компонент: казеїноцементний, газогенератор, пемзобетон. 
За способом зв'язку компонентів у складних словах виділяють складні терміни УДБТ, утворені:

- за допомогою сполучних морфем -е-, -є-, -о-: гравієсортувалка, грунтовирівнювач, кремнеземистий, м'якопластичний, тонкозернистий, хвилеутворення;

- без сполучних морфем: вінілпласт, карбамідформальдегідний, крафтмішок, кумаронбетон, набризкбетон, полімериемент, портландиемент;

- за допомогою способу складання, що супроводжується суфіксацією: асфальтоукладальник, каменеобробляння, вапнорозкидач.

За видом зв'язку серед складних терміносполук УДБТ виокремлюємо:

- терміни, компоненти яких пов'язані на основі сурядного зв'язку (копулятивні): торфобетон (торф і бетон), шлакобетон (шлак і бетон);

- терміни, компоненти яких пов'язані на основі підрядного зв'язку (атрибутивні): льодоутворення (утворення льоду), вантажкопотік (потік вантажу), зносостійкий (стійкий до зношування), руслоутворення (утворення русла).

Серед досліджуваних термінів значну частку утворюють складні прикметники, напр.: дорожньо-будівельні матеріали, гравієво-піщані матеріали, пружно-в'язка деформація, пружно-пластична деформація, дорожньо-кліматична зона, емульсивно-мінеральні суміші, піщано-гравійна подушка, полімерно-бітумне в'яжуче, перехідно-швидкісна смуга, щебенево-мастичний асфальтобетон, сульфітно-спиртова барда, щоглово-двостріловий кран, балково-консольний міст, цементо-бетонне покриття, шлако-зольний цемент.

Проаналізований матеріал дає підстави стверджувати, що композитиприкметники творяться з допомогою інтерфіксів, що характерно для основоскладання, і сурядного зв'язку, що відповідає словоскладанню.

Словоскладання - це процес утворення одного складного слова шляхом злиття кількох. Результатом словоскладання є юкстапозити (лат. jüхta - поряд і positio - місце). Науковці доводять, що появу в українській мові способу словосполучуваності та словоскладання без з'єднувального голосного зумовив вплив німецьких складних слів, наприклад: блок-секція, блоксхема. У ДБТл зростає кількість термінів-юкстапозитів, серед них, напр.: міст-канал, напіввиїмка-напівнасип, траншея-полиия, щільномір-вологомір, вакуум-апарат, вакуум-бетон, добавка-уповільнювач, корчувач-збирач, кранбалка, плита-підкладка, коток-тандем, фільтр-насос, щебінь-котун тощо. За характером твірної бази серед таких термінів виділяємо:

- прикладкові сполучення, тобто поєднання в одне ціле означуваного та означувального, наприклад: бункер-дозатор, труба-випуск, димосос-пиловловлювач, технік-архітектор, технік-конструктор, повітроочисник-іонізатор;

- найменування з числовим показником, або словесно-цифрові сполучення, наприклад: Дина-3M (метод динамічного навантаження); $A-1, A-2$, $A-3$ (районування території України за кліматичними умовами роботи асфальтобетонних покриттів); $H-13, H K-80$ (показники тимчасового мостового навантаження); $\boldsymbol{y}$-1, $\boldsymbol{y}$-2 (позначення дорожньо-кліматичних зон України); Урал-55224 (марка автомобіля-самоскида); 
- повтори, що є редуплікацією певного слова: гама-гама каротаж, нейтрон-нейтрон каротаж.

Терміни-юкстапозити можуть бути утворені внаслідок поєднання як національних, так і запозичених компонентів за такими схемами:

- національний компонент + іншомовний компонент і навпаки: крекінг-установка, інжектор-змішувач, цегла-сирець, цемент-гармата;

- національний компонент + національний компонент: добавка-наповнювач, корчувач-збирач, щільномір-вологомір;

- іншомовний компонент + іншомовний компонент: вакуум-бетон, грейдер-елеватор, термос-бункер.

Словоскладання та основоскладання в УДБТ найбільшого поширення набуло в трьох із чотирьох виділених раніше ТГ, у які об'єднані назви конкретних предметів і їх ознак:

1. ТГ «2. Назви дорожньо-будівельних матеріалів», підгрупи «2.3. В’яжучі матеріали», «2.4. Поверхнево-активні речовини (ПАР) та добавки» i «2.5. Бетони»: гумо-бітумні мастики, бітумно-щебенева суміш, шлако-зольний грунт, гідрофобно-пластифікуюча добавка, феритно-перлітний, щебеневомастиковий асфальтобетон.

1. ТГ «3. Дорожньо-транспортні споруди», підгрупа «3.5. Споруди мостового типу»: міст-водовідвод, міст вертикально-підіймальний, міст балково-консольний, міст рамно-балковий, міст рамно-консольний, міст рамно-підвісний, міст збірно-монолітний, міст збірно-розбірний, міст пальовоестакадний, міст температурно-нерозрізний.

2. ТГ «4. Засоби механізації для будівництва і ремонту автомобільних доріг», підгрупи «4.2. Машини для землерийних робіт» і «4.11. Машини для ремонту і утримання всіх типів доріг»: машина тунельно-бурова, nідмітально-прибиральна, машина поливально-мийна, кран-еректор; багатоківшевий, пневмоколісний, гідростатичний, гідродинамічний одноківщевий (екскаватор), напівпричепний, самохідний (грейдер); двовісний автогрейдер.

\section{Висновки}

Юкстапозитний і композитний способи словотворення на сучасному етапі розвитку посіли надзвичайно важливе місце у сфері термінології галузі ДБ, забезпечивши утворенням задовільних за своїми параметрами термінів. Актуалізація вказаних способів зумовлена тим, що прагнення повноти певного наукового поняття достатньою мірою може бути підтримане кількаосновними чи кількаслівними номінатами, репрезентованими як одне слово. Аналіз термінів-композитів галузі ДБ засвідчив, що серед них переважають двоосновні складні утворення, але зафіксовані й терміни з декількома основами: автобетономішалка, армопінобетон, армопіносилікат, високотермостійкий, дьогтебітумнополімерний, дегідрополіконденсація. Юкстапозитний і композитний способи словотворення в УДБТ найбільшого поширення набули в трьох із чотирьох виділених тематичних груп. Перспективи досліджень убачаємо в розгляді динаміки української дорожньо-будівельної термінології на сучасному етапі, зокрема з погляду структурної організації. 


\section{ЛІТЕРАТУРА}

1. Лопатин В. В. Рождение слова. Москва : Наука, 1973. 153 с. 2. Марченко В. С. Основні способи термінотворення. Культура слова. 1980. Вип. 18. С. 36- 40.

\section{REFERENCES}

1. Lopatyn, V. V. (1973). Rogdenye slova. [Birth of the word]. Moscow: Nauka [in Russian]. 2. Marshenko V. S. (1980), Osnovni sposoby termynotvorennya [The main ways of terminating]. Cultura slova - Culture of the word, 18, 36-40 [in Ukrainian].

Книшенко Наталія Петрівна - кандидат філологічних наук, доцент, доцент кафедри українознавства, Харківський національний автомобільно-дорожній університет; вул. Ярослава Мудрого, 25, Харків, 61002, Україна.

Тел.: +38-095-584-89-08

E-mail: knishenko@meta.ua

http://orcid.org/0000-0002-0803-2774

Knyshenko Nataliia Petrivna - PhD in Philology, Associate Professor, Department of Ukrainian studies, Kharkiv National Automobile and Highway University; Yaroslava Mudroho Str., 25, Kharkiv, 61002, Ukraine.

Надійшла до редакції 03 березня 2019 року 